\title{
TIMBER WASTES TORREFACTION FOR ENERGY USE
}

\author{
Guilherme da Silva Grassmann ${ }^{1}$, Carlos Rogério Andrade ${ }^{1, \diamond}$, Ananias Francisco Dias Júnior ${ }^{l}$, \\ Francides Gomes da Silva Júnior ${ }^{1}$, José Otávio Brito ${ }^{1}$
}

\begin{abstract}
The experiment consists in the realization of timber wastes torrefaction at a final temperature of $280{ }^{\circ} \mathrm{C}$, with heating rates of $0,5^{\circ} \mathrm{C} \cdot \mathrm{min}^{-1}$, with 1 hour permanence in the final temperature. Three different types of wastes were analyzed by composition. Moisture content, bulk density, torrefied mass yield, gross calorific value, particle size, and physical and mechanical resistance were determined. Except the moisture content, the remaining variables were evaluated before and after torrefaction. The results indicated that torrefaction increased the wastes energy density. The torrefied material yield was influenced by the particle size. Bulk density was reduced; however, the mass reduction was higher than the volume reduction. The calorific value was increased for all types of torrefied wastes. Torrefied wastes friability was higher compared to in natura wastes.
\end{abstract}

Keywords: Biomass, energy, calorific value, heat treatment, energy properties.

\section{INTRODUCTION}

For several years the Brazilian timber industry considered the wastes as a major problem of wood processing, and the main destination was the disposal in landfills (waste, garbage), or incineration, with the purpose of just clearing the storage yards, without any concern for its possible energy potentials (Biasi and Rocha 2007). It is estimated that in Brazil are generated, annually, about 30 million tons of wood wastes. The main generating source is the wood industry $(90,7 \%)$; followed by the wastes generated in urban areas $(6,3 \%)$ and in civil construction (3\%) (Tuoto 2009).

According to Couto et al. (2004), the rational use of biomass has not been fully effective due to its physical heterogeneity, such as, for example, shape and moisture, and also regarding the chemical composition.

An alternative to mitigate the heterogeneity negative effects, common to timber wastes, is the heat treatment applied to the material, a technique called torrefaction, which comprises the use of temperatures ranging from $200^{\circ} \mathrm{C}$ to $300^{\circ} \mathrm{C}$, according to the references of Brito (1993), Duchez and Guyonnet (2002), Pincelli et al. (2002) and Almeida et al. (2009). The heat treatment of wood reduces the equilibrium moisture content (Esteves et al. 2008, Yalcin and Ibrahim 2015) and its dimensional stability increased (Esteves et al. 2007), in addition, the heat treatment, according to Candelier et al. (2015), shows it an attractive alternative for improving resistance to deterioration of wood species with low natural durability, being however, that this improvement is accompanied by a reduction in mechanical properties, which is strongly correlated to thermal degradation of the components of the cell walls, among other benefits. 
Torrefaction allows obtaining an intermediary material between the in natura material and the charcoal, with high gravimetric yields, a process that presents a low energy demand (Felfli 2003). The fuel produced in this process offers better energy features, which final product characteristics vary depending on the final temperature and time under the influence of this temperature, in addition to the heating speed and the initial properties of each material (Rodrigues 2009).

The torrefaction temperature range comprises a global reaction of exothermic character. According to Brito (1993), in this range, $220^{\circ} \mathrm{C}$ to $300^{\circ} \mathrm{C}$, fuel gases, such as water steam, $\mathrm{CO}_{2}$, formic acid and acetic acid are produced. Brito (1992) states that the greater mass loss in pyrolysis occurs ranging from $240^{\circ} \mathrm{C}$ to $320^{\circ} \mathrm{C}$.

It is important to highlight that, beyond the energy advantages, torrefaction enables the material features homogenization, facilitates the starting to burn due the biggest surface contact by sprayed state , increases resistance to biological degradation, and reduces the material hydrophobicity (Brito 1993).

Further studies on the torrefaction area are considered of essential importance aiming to provide additional subsidies to anyone who might be interested in the process adoption. In the specific case, the present research intended to contribute to it, considering the torrefaction of different types of wood wastes regarding its compositions.

\section{MATERIALS AND METHODS}

\section{Material, characterization and torrefaction of wood wastes}

Timber wastes used in the energy supply of two ceramist poles located in the cities of Itu and Tatuí, State of São Paulo, Brazil, were used. As a first step the wastes components were manually sorted, in an attempt to qualify its compositions. This step resulted in the classification available on Table 1.

Table 1. Wood wastes classification.

Waste Composition

A Pinus spp chips obtained from slab chipping, containing bark pieces and sawdust

B Chips of various types of materials from furniture demolition and civil construction materials, such as: chipboard, MDF, plywood, solid wood and hardboard.

C Eucalyptus spp chips obtained from slab chipping, with few pieces of bark and sawdust.

Materials were chosen, not in the strict sense for performing comparisons between them, but rather for the purpose of having a more representative range of wastes.

At the end of drying, the samples, in the absolutely dry state were initially placed within sealed metal boxes, endowed with holes and access port for the evacuation of process gas and to introducing inert gases into the internal atmosphere. The torrefactions were performed under nitrogen flow of 30 $\mathrm{ml} / \mathrm{min}$, as described by Santos (2012) as well as laboratory routine. The final temperature was $280^{\circ} \mathrm{C}$, with a heating rate of $0,5^{\circ} \mathrm{C} \mathrm{min}{ }^{-1}$ and permanence time of 60 minutes at final temperature. Three torrefactions repetitions were carried out for each type of waste studied. The equipment that was used for the torrefactions was an electric oven Fanem - 320-Digital model, equipped with heating system by electrical resistance and forced circulation of internal air with a nominal volume of 450 liters. 
The heat treatments and the analyses were conducted in the Chemistry, Pulp and Energy Integrated Laboratories (LQCE), of the Forest Sciences Department of Escola Superior de Agricultura "Luiz de Queiroz" - ESALQ, of Universidade de São Paulo - USP.

Physical properties: The moisture content was determined using in natura waste, according to the Equation 1.

$$
U=\frac{M U-M S}{M U} x 100
$$

Whereas: $\mathrm{U}=$ waste moisture (\%); $M U=$ moistured waste mass $(\mathrm{kg}) ; M S=$ dry waste mass $(\mathrm{kg})$.

The in natura waste and torrefied wastes bulk density were calculated by Equation 2 .

$$
\text { Dgranel }=\frac{m}{v}(2)
$$

Whereas: Dgranel $=$ bulk density $\left(\mathrm{kg} \cdot \mathrm{m}^{-3}\right) ; \mathrm{m}=$ waste mass $(\mathrm{kg}) ; \mathrm{v}=$ waste volume $\left(\mathrm{m}^{3}\right)$.

The procedure used for the analysis of bulk density was based on Brazilian standard for determination of bulk density, whose reference is the NBR 6922 (ABNT 1981). In this case, an adaptation of the standard was made for the conditions of this study, on which the use as described in the standard of a rigid box $(600 \times 600 \times 600) \mathrm{mm}$ of internal dimensions had to be replaced by a beaker of capacity 1 liter or $1000 \mathrm{~cm}^{3}$. At the moment of the analysis, the inside of the beaker was carefully filled with waste, without, however, be any movement of the agitation. The mass assembly (beaker more residues) was obtained with the aid of an analytical balance accurate to $0,001 \mathrm{~g}$. To determine the volume, the container was filled with water to its maximum volumetric capacity, and also with the aid of a scale, their value equivalent in $\mathrm{m}^{3}$, was obtained. The test was done both for the material in natura in the absolutely dry state and for the roasted material.

Gravimetric yield: The torrefied wastes yield was determined on the basis of Equation 3.

$$
R M T=\frac{M T}{M O} x 100(3)
$$

Whereas: RMT = torrefied mass yield (\%); $M T=$ torrefied waste mass $(\mathrm{kg}) ; M O=$ mass of waste in nature, in the absolutely dry state $(\mathrm{kg})$.

Gross calorific value: The gross calorific value was determined using a calorimetric pump model Ika C200, following the procedures described by the standard NBR 8633 (ABNT, 1984).

Particle size: The granulometric analysis was determined using in natura wastes and torrefied wastes, according to the standard NBR 7402 (ABNT, 1982), aiming to determine the percentage of each material retained on the 16,8 and $4 \mathrm{~mm}$ sieves and in the tray $(<4 \mathrm{~mm})$. The screen was metallic and the values match the openings in mm on each sieve.

Friability: For this analysis the wastes were grinded in a Jokro-Muhle centrifugal mill, applying the standard MERK-BLATT V/105-VZIPC (Verein der Zellstoff und Papier Chemiker und Ingenieure), with grinding time of two minutes. The percentage of material retention in sieves of different gramulometries, comparing to the previous state and after the grinding, was used as a reference for an indication of physical and mechanical resistance, as proposed by Santos (2012). 
Statistical analysis: Student t Test was used to verify the difference between treatments. A Paired observation test was used, which aims to analyze the before and after of a variable. Variance analyses (ANOVA) were carried out, followed by the Tukey mean test, to a level of $5 \%$ of error probability.

\section{RESULTS AND DISCUSSION}

Physical properties: Table 2 shows the results for wastes moisture and bulk density before and after torrefaction.

Table 2. Average values of wastes moisture and bulk density before and after torrefaction.

\begin{tabular}{llll}
\hline Waste & Moisture (\%) & D.G.R. $\left(\mathbf{k g} / \mathbf{m}^{3}\right)$ & D.G.R.T $\left(\mathbf{k g} / \mathbf{m}^{3}\right)$ \\
\hline A & $32,50(5,78) \mathrm{a}$ & $245,72(3,62) \mathrm{a}$ & $217,41(1,49) \mathrm{c}$ \\
$\mathrm{B}$ & $23,27(5,46) \mathrm{b}$ & $245,21(0,33) \mathrm{a}$ & $197,29(5,22) \mathrm{b}$ \\
$\mathrm{C}$ & $10,43(3,93) \mathrm{c}$ & $166,54(2,38) \mathrm{b}$ & $152,77(1,89) \mathrm{a}$
\end{tabular}

Averages with equal letter do not differ statistically by Tukey test $(\alpha=0,05) ;$ D.G.R. $=$ Bulk density of in natura wastes; D.G.R.T. = Bulk density of torrefied wastes. Values in parentheses correspond to variation coefficient.

The analyses of in natura materials confirmed the expectation that significant differences would occur in its features results, comprising moisture and bulk density.

The results for moisture content were statistically different from each other, and had an average maximum values of $32,5 \%$ and minimum of $10,43 \%$; as seen in the table.

A definitive explanation of why this great difference between residues A and C, respectively, it is difficult to find. However, the time of exposure to weather, storage conditions, the dimensions of the chips as well as its chemical and anatomical makeup, maybe can help, together, to justify this variation. Fact is, that one can not attribute this change to only one factor, since there are many possibilities of interference.

After torrefaction, all materials featured significant reductions in bulk density, compared to their states in natura, being $11,52 \% ; 19,54 \% ; 8,27 \%$; respectively, for the A, B and C wastes. The results were a consequence of the weight loss caused by the degradation of wood constituents, such as polysaccharides and compounds of lower molecular mass and extractives. This observation was also done by Esteves and Pereira (2009) which reporting that the degradation of hemicellulose in volatile products and evaporation of wood extractives are the main reasons for the decrease in density. The authors claim that the loss of mass is one of the most important characteristics of heat treatment and this loss depends on species, heating means, temperature and treatment time.

It is also noticed that wastes with higher bulk density tended to suffer further reduction of this variable after torrefaction. Waste $\mathrm{C}$, for example, which initially had the lowest bulk density, showed the slightest mass reduction per volume unit. The remaining wastes showed relatively high mass loss after the torrefaction process. 
Gravimetric yield: Figure 1 shows the wastes yield values after torrefaction.

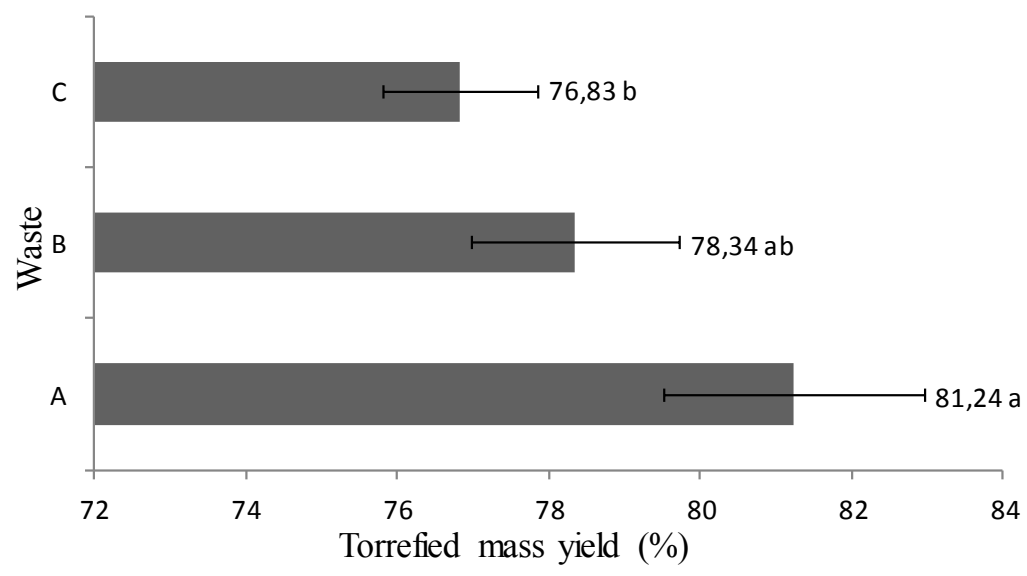

Figure 1. Average values of mass yield of torrefied wastes (RMT).

As shown in Figure 1, the wastes submitted to torrefaction showed mass loss due to natural process of biomass thermal degradation. In general, yields obtained were within the results available in the literature, such as those mentioned by Rodrigues (2009), which working with Eucalyptus grandis wood with the same temperature levels $\left(280^{\circ} \mathrm{C}\right.$ for $1 \mathrm{~h}$ ), obtained a gravimetric yield of $80,15 \%$. Pincelli (2011) in turn, using final temperature of $260^{\circ} \mathrm{C}$, with the same heating rate and the same level, of one hour, found 80,5\% yield for Pinus spp. and 76,1\% for Eucalyptus spp.

Waste A formed by Pinus spp chips showed the greatest yield. Waste B, which mostly comprises reconstituted materials, has slightly lower yield. It can be hypothesized that the presence of chipboards, MDF and plywood in waste B is the cause of that result. In such material composition, there is the participation of adhesives, which would have been more intensely removed during heat treatments, in proportion to the biomass and waste C Eucalyptus spp.

Gross calorific value: Table 3 shows the gross calorific values (PCS) of the studied wood wastes.

Table 3. Average values of wastes gross calorific values (PCS) before and after torrefaction.

\begin{tabular}{llllll}
\hline \multirow{2}{*}{ Waste } & In natura & \multicolumn{3}{c}{ Torrefied } & G a i n \\
\cline { 2 - 5 } & PCS $(\mathrm{kcal} / \mathrm{kg})$ & $\mathrm{CV}(\%)$ & $\mathrm{PCS}(\mathrm{kcal} / \mathrm{kg})$ & $\mathrm{CV}(\%)$ & \% \\
\hline $\mathrm{A}$ & $4,875 \mathrm{~b}$ & 0,39 & $5,278 \mathrm{a}$ & 0,22 & 8,27 \\
$\mathrm{~B}$ & $4,841 \mathrm{~b}$ & 0,81 & $5,073 \mathrm{~b}$ & 0,91 & 4,79 \\
$\mathrm{C}$ & $4,550 \mathrm{a}$ & 0,05 & $5,147 \mathrm{ab}$ & 0,07 & 13,12
\end{tabular}

$t$ Test $=8,49^{*}$

$\mathrm{CV}=$ Variation Coefficient; $\left({ }^{*}\right)$ indicates significant value at $5 \%$ of error probability, with $\mathrm{GL}=5$, where $\mathrm{t}$ tab. $=2,57$.

For in natura wastes, higher PCS values were observed for the samples comprising Pinus spp. wastes (A), and wastes comprising reconstituted materials (B), compared to those only originated of solid wood (C). The presence of resin in Pinus spp wood and adhesives in reconstituted materials could explain such results.

Results demonstrated an increase in gross calorific values of torrefied materials, with values ranging from 8 to $13 \%$, as compared to in natura wastes. Possibly, such increases are related to the increase of fixed carbon content provided by torrefaction, as shown by Rodrigues (2009) and Pincelli (2011). 
Particle size: Figure 2 shows the granulometry values of in natura wastes, in $16 \mathrm{~mm}, 8 \mathrm{~mm}, 4 \mathrm{~mm}$ sieve and tray $(<4 \mathrm{~mm})$. Figure 3 snows the granulometry values of torrefied wastes for the same sieves.

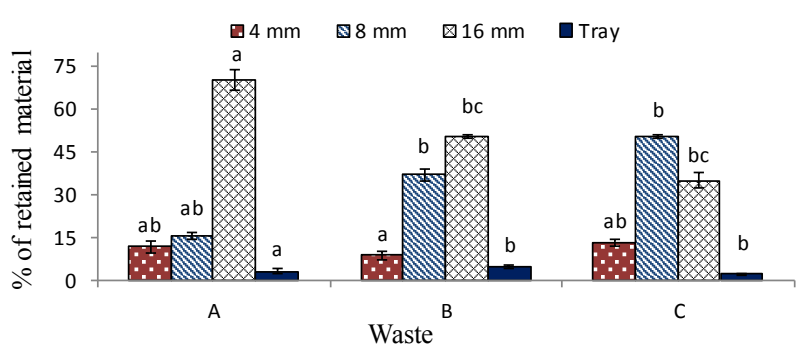

Figure 2. Particle sizes average values of the studied wastes before and after torrefaction.

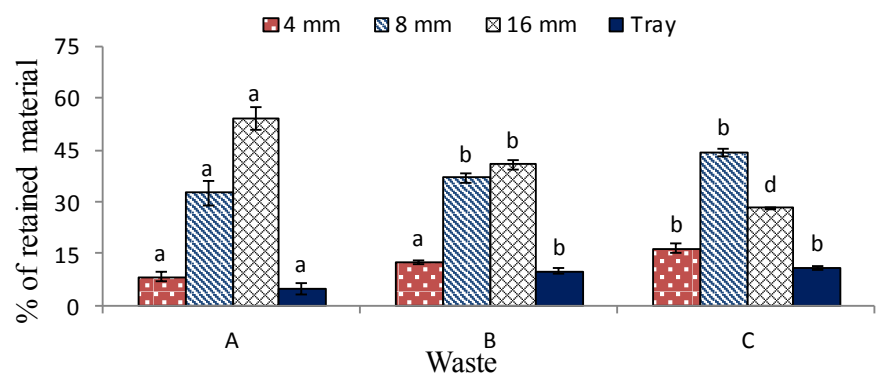

Figure 3. Particle sizes average values of the studied wastes after torrefaction.

Comparing Figures 2 and 3, it can be noticed that torrefaction influenced in wastes particle size reduction. This can be verified by the mass reduction of particles retained on thicker sieves, and the consequent mass increase of particles in finer sieves. Such behavior indicates that there was a reduction in particle size as a function of weight loss caused by torrefaction. The results show that the larger mesh sieve strains retained less waste after the treatment, because many of these particles lose mass and passed through the mesh where it was previously not possible.

Friability: Tables 4 and 5 show particle size values of wastes submitted to friability test before and after torrefaction, respectively.

Table 4. Average granulometry values for in natura wastes subjected to grinding test.

\begin{tabular}{lllll}
\hline \multirow{2}{*}{ Waste } & \multicolumn{5}{l}{ Sieve mesh opening $(\mathbf{m m})$} \\
\cline { 2 - 5 } & $16(\%)$ & $8(\%)$ & $4(\%)$ & Tray $(\%)$ \\
\hline $\mathrm{A}$ & $58,23(5,56) \mathrm{a}$ & $20,49(2,44) \mathrm{a}$ & $14,36(13,30) \mathrm{abc}$ & $6,78(33,04) \mathrm{a}$ \\
$\mathrm{B}$ & $40,17(0,90) \mathrm{b}$ & $31,22(4,13) \mathrm{c}$ & $11,23(16,56) \mathrm{abd}$ & $17,30(10,46) \mathrm{d}$ \\
$\mathrm{C}$ & $31,85(3,77) \mathrm{c}$ & $48,97(4,59) \mathrm{d}$ & $15,47(4,59) \mathrm{bc}$ & $3,67(30,24) \mathrm{a}$ \\
\hline
\end{tabular}

Values in parentheses correspond to the variation coefficient $(\%)$. 
Table 5. Average granulometry values for torrified wastes subjected to grinding test.

\begin{tabular}{lllll}
\hline \multirow{2}{*}{ Waste } & \multicolumn{4}{l}{ Sieve mesh opening (mm) } \\
\cline { 2 - 5 } & $16(\%)$ & $8(\%)$ & $4(\%)$ & Tray $(\%)$ \\
\hline A & 0,00 & $1,17(11,97) \mathrm{a}$ & $2,90(43,10) \mathrm{ab}$ & $95,74(1,08) \mathrm{ab}$ \\
$\mathrm{B}$ & 0,00 & $0,44(72,73) \mathrm{a}$ & $5,71(10,33) \mathrm{bc}$ & $93,68(0,50) \mathrm{ab}$ \\
$\mathrm{C}$ & 0,00 & $7,75(20,77) \mathrm{b}$ & $35,31(2,72) \mathrm{d}$ & $56,81(4,54) \mathrm{c}$ \\
\hline
\end{tabular}

Values in parentheses correspond to the variation coefficient $(\%)$.

On the basis of Tables 4 and 5 , it is noticed that wastes that have not been submitted to torrefaction, when being subjected to grinding test, showed dramatically less fragmentation than that observed in torrefied wastes. Therefore, the references provided by Burgois (1985) and Santos (2012) were confirmed, and the torrefaction process increases the materials friability. The degradation of hemicelluloses has been placed by Korkut and Aytin 2015 as the main factor for the loss of mechanical strength of wood after heat treatment.

\section{CONCLUSIONS}

In general, the differences in the wastes composition influenced, significantly, the results obtained in the different characterizations performed, comprising both in natura materials and torrefied materials. Wastes torrefaction yields showed values compatible with those available in specialized literature, and were significantly distinct between the different materials. There was a significant decrease in bulk densities of torrefied wastes, when compared to densities of in natura wastes. There were significant gains of gross calorific value in torrefied materials, compared to in natura materials. There was a significant reduction in the torrefied materials granulometry, compared to in natura materials and, in the same proportion; there was an increase in the materials granulometric homogeneity after heat treatment. The torrefied materials were significantly more friable than in natura wastes, indicating a greater grinding easiness aiming the energy use of materials in sprayed form.

For the industrial sector that requires thermal energy in their processes, the adoption of torrefaction of wood waste represents a real alternative for improvements and gains in its processes, since it would have as raw material a renewable product, more homogeneous in structure and chemicals, less hygroscopic, more energy, and more friable.

The biggest friability of these tosted enable to the waste still be ground and pulverized easily directly in furnaces and boilers. This procedure besides being able to be completely automated, improves the efficiency of burning inside the furnace, due the existence of greater surface of contact on the particulate form compared to the solid material in natura.

\section{REFERENCES}

Almeida, G.; Brito, J.O.; Perré, P. 2009. Changes in wood-water relationship due to heat treatment assessed using micro-samples of Eucalyptus. Holzforschung 63(1): 80-88.

Associação Brasileira De Normas Técnicas. ABNT. 1981. NBR 6922: determinação de densidade a granel. Rio de Janeiro. 3p.

Associação Brasileira De Normas Técnicas. ABNT. 1982. Associação Brasileira De Normas Técnicas. NBR 7402: carvão vegetal - determinação granulométrica. Rio de Janeiro.

Associação Brasileira De Normas Técnicas. ABNT. 1984. Associação Brasileira De Normas Técnicas. NBR 8633: carvão vegetal - determinação do poder calorífico. Rio de Janeiro.

Biasi, C.P.; Rocha, M.P. 2007. Rendimento em madeira serrada e quantificação de resíduos para três espécies tropicais. Floresta 37(1): 95-108. 
Brito, J.O. 1992. Estudo das influências da temperatura, taxa de aquecimento e densidade da madeira de Eucalyptus maculata e Eucalyptus citriodora sobre os resíduos sólidos da pirólise. $88 \mathrm{f}$. Tese (Livre Docência na Universidade de São Paulo), ESALQ/USP, Piracicaba.

Brito, J.O. 1985. Estudo preliminar de retificação térmica da madeira de eucalipto. In: Congresso Florestal Brasileiro, n. 7, Curitiba. Anais. Curitiba: SBS/SBEF, p.774, 1993.

Bourgois, J.P. 1985. Torrefied Wood from temperate and tropical species, advantages and prospects. Bioenergy 84:153-159.

Candelier, K.; Hannouz, S.; Elaieb, M.; Collet, R.; Dumarçay, S.; Pétrissans, A.; Gérardin, P.; Pétrissans, M. 2015. Utilization of temperature kinetics as a method to predict treatment intensity and corresponding treated wood quality: Durability and mechanical properties of thermally modified wood. Maderas. Ciencia y tecnología 17(2): 253-262.

Couto, L.C.; Couto, L.; Watzlawick, L. F.; Camara, D..2004. Vias de valorização energética da biomassa. Biomassa \& Energia 1(1): 71-92.

Duchez, L.; Guyonnet, R. 2002. Principles and applications of wood retification.

Esteves, B.; Domingos, I.; Pereira, H. 2007. Improvement of technological quality of eucalypt wood by heat treatment in air at $170-200^{\circ} \mathrm{C}$. Forest Prod $J 57$ (1-2): 47-52.

Esteves, B.; Marques, A.V.; Domingos, I.; Pereira, H. 2008. Heat-induced colour changes of pine (Pinus pinaster) and eucalypt (Eucalyptus globulus) wood. Wood Science and Technology 42(5):369-384.

Felfli, F. 2003. Torrefação de Biomassa. Viabilidade Técnica e Potencial de Mercado. 180 f. Tese (Doutorado em Sistemas Energéticos) - Faculdade de Engenharia Mecânica - FEM, Universidade Estadual de Campinas - UNICAMP, Campinas, São Paulo.

Pincelli, A.L.P.S.M. 2011. Características dos resíduos da colheita de madeira de eucalipto e pinus, submetidos ao tratamento térmico, com foco na aplicação energética. $127 \mathrm{f}$. Tese (Doutorado em Tecnologia de Produtos Florestais) - ESALQ/USP, Piracicaba.

Pincelli, A.L.P.S.M.; Brito, J.O.; Corrente, J.E. 2002. Avaliação da termorretificação sobre a colagem na madeira de Eucalyptus saligna e Pinus caribaea var. hondurensis. Scientia Forestalis 61:.122-132.

Rodrigues, T.O. 2009. Efeitos da torrefação no condicionamento de biomassa para fins energéticos. 82 f. Dissertação (Mestrado em Ciências Florestais) - Faculdade de Tecnologia da Universidade de Brasília, Brasília.

Santos, J.R.S. 2012. Estudo da biomassa torrada de resíduos florestais de eucalipto e bagaço de cana-de-açúcar para fins energéticos. 86 f. Dissertação (Mestrado em Tecnologia de Recursos Florestais) - ESALQ/USP, Piracicaba.

Tuoto, M. 2009. Levantamento sobre a geração de resíduos provenientes da atividade madeireira e proposição de diretrizes para políticas, normas e condutas técnicas para promover seu uso adequado. Ministério do Meio Ambiente, Curitiba, 35 p.

Verein der zellstoff und papier chemiker und ingenieure. Merkblatt V/105-VZIPC.

Korkut, S.; Aytin, A. 2015. Evaluation of physical and mechanical properties of wild cherry wood heat-treated using the thermowood process. Maderas. Ciencia y tecnología 17(1): 171-178.

Yalcin, M.; Ibrahim, H. 2015. Changes in the chemical structure and decay resistance of heattreated narrow-leaved ash wood. Maderas. Ciencia y tecnología 17(2): 435-446. 